\title{
Understanding and responding to diversity in the primary classroom: an international study
}

Neil Humphrey ${ }^{\mathrm{a}}$, Paul Bartolo ${ }^{\star b}$, Peter Ale ${ }^{\mathrm{c}}$, Colin Calleja ${ }^{\mathrm{b}}$, Thomas Hofsaess ${ }^{\mathrm{d}}$, Vera Janikova ${ }^{\mathrm{e}}$, Annemieke Mol Lous ${ }^{\mathrm{c}}$, Vida Vilkiene ${ }^{\mathrm{f}}$ and Gun-Marie Wetso ${ }^{\mathrm{g}}$

${ }^{\mathrm{a}}$ University of Manchester, UK; ${ }^{\mathrm{b}}$ University of Malta, Malta; ${ }^{\mathrm{c}}$ Educatieve Hogeschool van Amsterdam, The Netherlands; ${ }^{\mathrm{d}}$ University of Leipzig, Germany; ${ }^{\mathrm{e}}$ Non-profit organisation Motivace-Zivotni Styl, Czech Republic; ${ }^{\mathrm{f}}$ Marijampole College, Lithuania; ${ }^{\mathrm{g}}$ Dalarna University, Sweden

The increased diversification of classrooms in recent years has placed additional demands upon teachers who strive to facilitate the learning and participation of all pupils. The aim of the current study was to explore how primary teachers across Europe understand and respond to diversity in their classrooms. A total of 35 teachers from 7 countries (Czech Republic, England, Germany, Holland, Lithuania, Malta, Sweden) participated in semi-structured interviews. Analysis of the data yielded several key themes: (i) the need for caring and inclusive attitudes and school ethos, (ii) facilitating inclusive values and solidarity in pupils, (iii) building collaborative networks, (iv) organising 'responsive' teaching, and ( $v$ ) facing challenges in responding to diversity. The implications of these findings for the development of inclusive practices are discussed.

Keywords: diversity, inclusion, primary education

Au cours des dernières années la diversification montante de la salle de classe a placé des exigences supplémentaires sur les professeurs qui essayent de faciliter l'éducation et la participation de tous les élèves. Le but de cette étude était d'examiner comment les professeurs du primaire, en Europe, comprennent et répondent à la diversité des enfants en classe.

Trente-cinq professeurs de sept pays au total (la République tchèque, l'Angleterre, l'Allemagne, la Hollande, la Lituanie, Malte et la Suède) ont participé aux entretiens assez structurés. Les analyses de données ont montré quelques thèmes importants:

a. Le besoin d'attitudes inclusives et humaines et la culture de l'école.

b. Le besoin de faciliter les valeurs inclusives et la solidarité parmi les élèves.

*Corresponding author. University of Malta, Malta. Email: paul.a.bartolo@um.edu.mt 
c. Le besoin d'établir des réseaux de contacts en collaboration.

d. Le besoin d'organiser l'enseignement 'réceptif.'

e. Le besoin de s'occuper des défis en répondant à la diversité.

Les implications des recherches pour le développement des méthodes inclusives sont discutées.

Die gestiegene Heterogenität innerhalb der Schülerschaft stellt Lehrer, die danach streben, das Lernen und die Mitarbeit aller Schüler zu fördern vor zusätzliche Herausforderungen. Ziel der aktuellen Studie ist es, zu erforschen, wie Grundschullehrer in Europa Schülerheterogenität verstehen und darauf reagieren. Insgesamt 35 Lehrer aus 7 Ländern (Tschechische Republik, England, Niederlande, Litauen, Malta, Schweden, Deutschland) beteiligten sich an Leitfadeninterviews. Die Analyse der Daten erbrachte folgende Schlüsselthemen: (i) Notwendigkeit einer positiven und inklusiven Einstellung und Schulethos, (ii) Förderung inklusiver Werte und Solidarität bei den Schülern, (iii) Aufbau kooperativer Netzwerke, (iv) Organisation schülerorientierten Lernens und (v) Annehmen von Herausforderungen in der Interaktion hinsichtlich Heterogenität. Die Implikationen dieser Erkenntnisse für die Entwicklung inklusiver Praktiken werden diskutiert.

En los últimos años, la creciente diversificación en las aulas ha generado demandas adicionales en los maestros, que se esfuerzan por propiciar el aprendizaje y la participación de todos los alumnos. El propósito del presente estudio fue explorar cómo los maestros europeos de nivel primario conceptualizan y responden a la diversidad en sus clases. Un total de 35 maestros de 7 países (Alemania, Holanda, Inglaterra, Lituania, Malta, República Checa y Suecia) participaron de entrevistas semiestructuradas. El análisis de los datos arrojó un conjunto de temas clave: (i) la necesidad de propiciar la inclusión y el afecto, así como la revalorización de las actitudes y creencias que identifican a la escuela, (ii) la generación de valores de inclusión y solidaridad en el alumnado, (iii) la construcción de redes de colaboración, (iv) la implementación de enseñanza 'sensible', y (v) desafíos en el manejo de la diversidad. Este artículo discute las implicancias de estos resultados en el desarrollo de prácticas de enseñanza para la inclusión.

\section{Introduction}

In recent years schools in Europe have witnessed increasingly heterogeneous classrooms. Teachers are now faced with an extremely diverse range of pupils and are required to respond effectively to meet their needs. This amplified diversification can be seen as arising from three main sources. Firstly, at a cultural level, there have been increasing numbers of immigrants and general mobility within and across countries (Eurydice, 2002; European Commisson Directorate General for Education and Culture, 2003). Secondly, landmark policy developments (e.g. UNESCO, 1994) have led to increasing numbers of children with special educational needs attending mainstream schools (Farrell and Ainscow, 2002). Thirdly, there have been increasing concerns regarding the difficulties faced by pupils who fail to achieve adequate levels of literacy or drop out of school, together 
with an awareness of the multiplicity and complexity of competencies required in modern society (Eurydice, 1994; Gregory and Kuzmich, 2005).

Responding to the diverse and varied needs of pupils in the classroom forms one of the biggest challenges currently facing teachers (Tomlinson, 1999; Meijer, 2003), and there is a growing literature (both research and professional) in this area (e.g. McGarvey et al., 1998; Benincasa, 2002; Tomlinson, 2003; Donnelly, 2004; UNESCO, 2004). One influential model from the United States (Tomlinson, 2003) has proven particularly useful for researchers and practitioners alike. In attempting to become more 'responsive' practitioners, Tomlinson (2003) suggests, educators need to find an appropriate match between the diversity evident in pupil characteristics and that of the curriculum to be accessed (see Figure 1).

Despite the emergence and popularity of models such as that proposed by Tomlinson (2003), there exists comparatively little research that has explored how teachers actually understand, engage with, and respond to diversity in the classroom. Those studies that have been published to date (such as McGarvey et al., 1998) understandably focus on one particular aspect of practice (e.g. differentiation) within a specific national context (e.g. Northern Ireland). What is currently lacking in the literature in this area is research which takes a broader view of diversity and explores the experiences of teachers in differing contexts. The potential utility of such research is twofold. At a basic level it will undoubtedly facilitate the development of theoretical and practical knowledge regarding responsive teaching and inclusive practice. In the European Union in particular though, this kind of inquiry can also be seen as directly in line with the trans-national movement to support and respect diversity in all its forms (e.g. European Communities, 1997; UNESCO, 2005). The aim of the current study was to address this gap in the knowledge base.

\section{Differentiated teaching module (Primary)}

The current study was carried out as part of a larger project funded by the European Commission (Comenius 2.1), which began in 2004 and will be completed in 2007 .

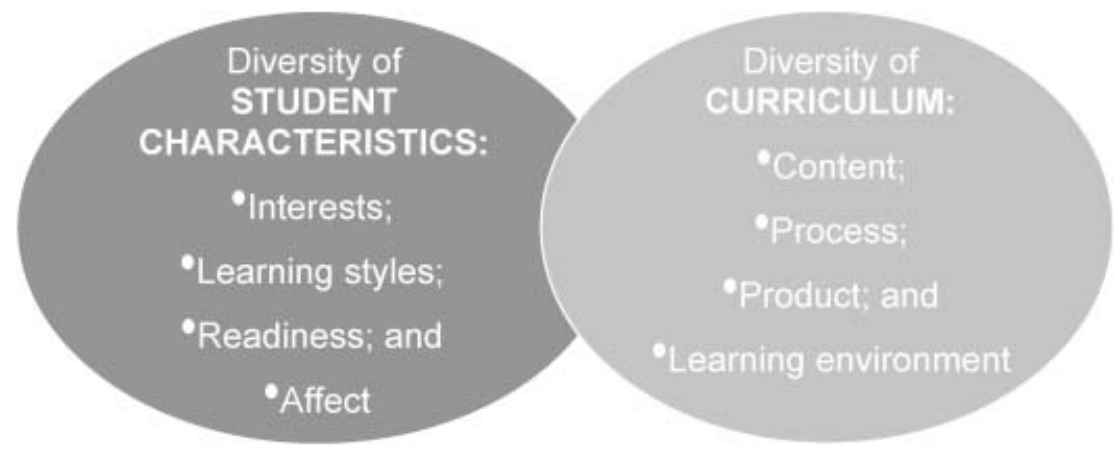

Figure 1. Matching a diversified curriculum to the diversity of student strengths and needs (adapted from Tomlinson, 2003). 
The overall aim of the project is to develop an Internet-based module for trainee teachers across the European Union (EU) that will enable them to respond more effectively to diversity in their classrooms (see www.dtmp.org for further details). The development of the Differentiated Teaching Module (Primary) (DTMp) has involved the collaboration of seven EU member states-Malta, the United Kingdom, Germany, Lithuania, Sweden, the Czech Republic and the Netherlands. However, before developing the module, we wanted to get a feel for how teachers across the EU perceived and responded to the challenge of reaching all pupils and what factors they considered important in the success or failure of their endeavours - thus, the current study was undertaken.

The following research questions drove our inquiry:

- Research Question 1-How do primary teachers understand and respond to diversity in European classrooms?

- Research Question 2-What are the key challenges to and enabling factors for effective practice in this regard?

\section{Method}

A qualitative design was adopted based on a constructivist paradigm - namely that there are multiple, socially constructed realities regarding the phenomenon in question (Lincoln and Guba, 2000). The rationale for this is that we felt that the research questions for the study could not be fully explored within a context-free quantitative paradigm-especially given the emphasis on the perspectives of participants. Conversely, qualitative methods are, by their nature, concerned with exploring the perspectives of participants and examining their experiences in the contexts in which they occur (Smith, 2003). Within this paradigm, we adopted semistructured interviews as our method of data collection. An initial interview schedule was developed by the authors and then piloted with one teacher from each participating country. The schedule was then refined before being implemented with the final sample of teachers (see below).

\section{Participants and sampling}

We 'purposively' sampled (Guba and Lincoln, 1989) a total of 35 teachers who were known to be actively trying to reach out to all pupils, with the hope of capturing successful processes as well as challenges. The following criteria were used to screen potential participants:

- Primary school teacher

- Received full professional training as a teacher

- Currently teaching full-time (and have been doing so for at least 12 months)

- Actively trying to respond to pupil diversity

The fourth criterion provides some obvious challenges in terms of rendering an objective view as to whether a particular teacher could participate-as such we were 
forced to rely on our professional judgement and knowledge of teachers in our respective countries.

In addition to the above criteria for inclusion in the study, we applied a stratification procedure involving the following dimensions:

- Five teachers would be interviewed from each country

- Each participant would be teaching in a different primary school

- As far as possible the selected sample would be teaching across the different ages of primary schooling-from 4 to 12 years

These dimensions were not applied in an attempt to achieve some measure or 'representativeness' or 'generalisability' - rather, they were applied in order for us to explore a range of contexts and thus enrich our analysis of the data. The combination of our purposive sampling and stratification procedure yielded a final sample that is summarised in Table 1:

Table 1. Summary of relevant sample characteristics.

\begin{tabular}{|c|c|c|c|c|}
\hline Country & $\begin{array}{l}\text { Teaching } \\
\text { experience of } \\
\text { participants } \\
\text { (range) }\end{array}$ & $\begin{array}{l}\text { Present class } \\
\text { age level } \\
\text { (range) }\end{array}$ & $\begin{array}{l}\text { Teaching } \\
\text { responsibilities }\end{array}$ & Support systems \\
\hline Malta & $6-11$ years & $5-10$ years & $\begin{array}{l}\text { Main class teacher (but } \\
\text { other teachers for } \\
\text { physical education, } \\
\text { music and art) }\end{array}$ & $\begin{array}{l}\text { School literacy support } \\
\text { teacher; teaching } \\
\text { assistant for children with } \\
\text { special educational needs }\end{array}$ \\
\hline $\begin{array}{l}\text { United } \\
\text { Kingdom }\end{array}$ & $4-10$ years & $5-11$ years & Main class teacher & $\begin{array}{l}\text { Teaching assistant for } \\
\text { children with special } \\
\text { educational needs; } \\
\text { teaching assistant for } \\
\text { children learning English } \\
\text { as a } 2^{\text {nd }} \text { language }\end{array}$ \\
\hline Germany & $22-31$ years & $8-10$ years & $\begin{array}{l}\text { Main class teacher, } \\
\text { (but with other } \\
\text { teachers for maths, } \\
\text { sport, music and art) }\end{array}$ & Pupil counselling support \\
\hline Lithuania & $9-30$ years & $7-11$ years & $\begin{array}{l}\text { Main class teacher (but } \\
\text { other teachers for } \\
\text { foreign language - } \\
\text { English) }\end{array}$ & $\begin{array}{l}\text { Speech therapist's } \\
\text { support; Special needs } \\
\text { educator support }\end{array}$ \\
\hline Sweden & $1-13$ years & $6-12$ years & Main class teacher & $\begin{array}{l}\text { Special needs educator } \\
\text { support }\end{array}$ \\
\hline $\begin{array}{l}\text { The Czech } \\
\text { Republic }\end{array}$ & $12-29$ years & $6-11$ years & Main class teacher & None \\
\hline $\begin{array}{l}\text { The } \\
\text { Netherlands }\end{array}$ & $4-25$ years & $4-12$ years & Main class teacher & $\begin{array}{l}\text { Support teacher for } \\
\text { children with special } \\
\text { needs }\end{array}$ \\
\hline
\end{tabular}




\section{Research and analytical procedure}

The revised version of the interview schedule centred on participants' conceptual understanding of diversity, their experiences in working with/responding to pupil diversity, support and training needs in relation to diversity, and perceived barriers to responding effectively to diversity.

As is commonly the case with qualitative research, the data collection and analysis procedures took place in tandem (Guba \& Lincoln, 2000). Each researcher initially performed a basic thematic analysis of the data from their pilot interview. Descriptive categories were generated and applied to textual passages. These descriptive categories were then merged into coherent analytical themes. Throughout this process the aims and research questions relating to the interviews were used to guide the organisation and interpretation of data. Consistent with accepted guidelines for analysing qualitative data, any examples of textual passages that did not conform to emergent themes ('negative cases' or 'divergences') were also noted (examples of these in the Results section are underlined).

The seven thematic analyses were collated and a common coding framework was developed for the analysis of subsequent interview transcripts. This coding framework was applied to each transcript and modified on an ad-hoc basis so as to provide an increasingly greater 'goodness of fit' with the data. The common coding framework bore 5 main themes, each with up to 8 subordinate themes. For the purposes of clarity and conciseness, only the main themes are presented and discussed here.

\section{Results}

The 5 main themes emerging from the analysis were: (1) the need for caring and inclusive attitudes and school ethos - all participants spoke of wanting to reach all students, believing and feeling accountable for each one's learning, caring about each one's progress and happiness, and enabling each one's participation. They mentioned the need for 'pedagogy conversations' in order to reflect and improve their responding. (2) The participants did not leave appreciation of diversity to chance but actively tried to develop inclusive and solidarity values in their students as they strived to build a classroom community. (3) In fact, participants also spoke of the need for building collaborative networks: firstly an interpersonal relationship with each of their students; secondly among their students; and finally with other school staff, parents and other professionals. (4) In addition, these teachers used a variety of strategies to organise responsive teaching, including group work and a diversified curriculum, for engaging the whole class in multi-interest, multi-media and multilevel activities, using a great deal of flexibility and creativity. (5) Finally, it was noted that teachers did not see responsive teaching as an easy option. They also spoke of how they tried to face challenges to responding to diversity-for instance, when the rest of the school did not share the same values, or when dealing with pupils with particularly complex needs. 


\section{The need for caring and inclusive attitudes and school ethos}

All the interviewees mentioned in one way or another that the teacher had to have, as a basic requirement for responding effectively to pupil diversity, an attitude in favour of respect for each student's entitlement to a quality education. This positive attitude was demonstrated through, amongst other things, a persevering belief in each child's potential, respect for each as an equal person, and a feeling of accountability for enabling progress in the classroom. Underpinning this was a conception of diversity as an enriching factor to classroom life, and the need for similarly inclusive values at the whole school level. The following extracts provide useful illustrations of this theme:

I mean, that's the beauty of our job: every June I'm sad to see one group leave, but we have a new group in our class every year. That's why I said October is very difficult, because you have to get to know them, you have to open these presents, you know, and you don't know what you're going to find, but it's our job to find it and to see what and how things are going to work out...[Teacher from Malta]

There are schools and teachers who feel differences as a big problem that makes them busy... But I cannot say that all the teachers work like that-there are teachers in our schools who study new approaches, work on themselves, change themselves ....and they do not push children to changes which satisfy them- teachers. ... Such teachers seek experiences from other experienced teachers, schools. ...After some time they begin to think about inclusion among adults (school workers, parents ...) -it is an advantage that we all are different. Such teachers begin (together with a child) to seek, develop his/ her talent. All participants in such a process begin to change their system of valueswhat is necessary for life, what we should teach at schools and how and with whom. [Teacher from Czech Republic]

...so there wasn't 'that's the boy with autism'. He's never had that label used, he's always been moulded as anybody — as a member of our school. [Teacher from United Kingdom]

You have to love your pupils... [Teacher from Lithuania]

To be honest we had the additional problem of the Kosovan children which had just come in that year [Teacher from the United Kingdom]

The final excerpt above, whilst being an example of a minor divergence from the overall theme, is noteworthy in that it demonstrates how easy it can be to 'problematise' certain groups of learners (in this case, refugee children)- this in turn is likely to lead to lowered expectations and possible social exclusion in the classroom. Overall though, the emergence of the theme of caring and inclusive attitudes and ethos is perhaps unsurprising-indeed, it is consistent with key literature in the area of inclusive education (e.g. Thomas and Loxley, 2001; Booth and Ainscow, 2002; Ainscow et al., 2004). As authors such as Ainscow, Howes, Farrell and Frankham (2003) have argued, values and attitudes consistent with inclusive principles alone provide no guarantee of inclusive and responsive practices, since the intensive encounters that occur during a typical lesson can often leave little room for the experimentation and innovation required in the process of attempting to reach all pupils (meaning that much of what teachers do is often carried out at an 
automatic, intuitive level). What has become evident in the research in this area is that teachers also need the opportunity to converse and collaborate with colleagues - in what Ainscow et al. (2004) have called 'interruptions' of established understandings and practices. This phenomenon was clearly evident in the current sample-for instance, a teacher from United Kingdom said, 'If we find there is anything that we feel that is a barrier or something crops up in school we usually discuss things and how best to address any barriers that generally arise or any problems'. The value of these 'pedagogical conversations' are of course likely to be contingent on the quality of collaborative relationships that have been established within a given school (see Theme 3 ). Where such relationships are difficult to establish, pedagogical conversations can be rare, as a teacher from Germany stated: 'It would help to have more time to talk to colleagues... I haven't seen a proper staff meeting for years, where all of us sit together and discuss'.

\section{Educate in solidarity}

The participants also felt the need to educate others to appreciate diversity. They engaged specifically in educating their whole class in an appreciation of diversity and the values of inclusion and solidarity, and worked towards building the class group as a small community - as one teacher from Malta stated, 'We are one family... we all belong to the same class-nobody should be left out'. These values were taught across the curriculum, and enabled the generation of dialogues about difference and diversity as positive dimensions of classroom experience that can be used to bring individuals together rather than divide them:

I have always tried to teach them that we are one community. Central is that we help each other, there's no mocking, and the better students agree to help the others. I don't always have to remind them of that, they do it of their own accord and offer their help. We're a good community. [Teacher from Germany]

In my class you see that the pupils that learn more easily influence the weaker children by offering a helping hand. On the other hand, for example, I have a girl that has a lot of trouble reading, but almost always helps the third graders with their reading assignment. So you see that a child that actually has a lot of trouble with reading can still put her knowledge to use by helping the younger children. [Teacher from Netherlands]

I choose something-food-that is important in every culture and every child has something unique to contribute to this subject. They also like to do this, because they can show how it works in their culture. For these kinds of conversations we always sit in a circle. Everybody sticks to the rules. This always goes faultless. [Teacher from Netherlands]

Pupils' internalisation of such values bodes well for their development as responsible and caring citizens. However, educating in solidarity was seen very much as a protracted, developmental process - as one teacher from the Czech Republic stated, 'We teach them to accept the others as they are-but it is a process... [a] longdistance run'. This sentiment was echoed by a teacher from Germany, who stated, 'It's very hard to unite all of them, [it] needs a lot of patience and calmness'. 
The theme of educating in solidarity, with its implicit values of acceptance and celebration of diversity, closely mirrors current political and cultural processes occurring within the European Union (EU). Like the heterogeneous classrooms our participants worked in, the EU consists of a multiplicity of cultures within and across the $25 \mathrm{EU}$ current member states and new applicants. While seeking to establish common democratic values, the EU at the same time supports existing cultural diversity and promotes respect for such diversity. 'The European Union's citizens are bound together by common values such as freedom, tolerance, equality, solidarity, cultural diversity...' (European Communities, 1997). The apparently paradoxical notion of Europeans being bound together by their diversity reflects the recognition, on the part of the Member States, that the objective of a European identity, based on a set of shared values, can only be achieved if a respect for diversity is established as one of them.

\section{Build collaborative networks}

Another frequent issue raised by the interviewees was the need for supportive relationship networks. Indeed, one teacher suggested that training in interpersonal skills was an essential preparation for responding to diversity. Participants variously referred to teacher-pupil relationships; relationships among the children; and relationships with other staff and parents. At the teacher-pupil level, a distinct feature of the current sample was their readiness to connect with their students-to build a personal individual relationship using methods such as self-disclosure or sharing of interests to 'get closer' (as stated by a teacher from Malta). These teachers reflected on the need to relate to each child, to be patient and persevering, and to be aware of how they themselves influenced the children. They tried to use the relationship as a motivation for more effort, and were sensitive to personal difficulties, trying to meet the children's needs for individual attention wherever possible:

You first have to get a relation with the one they should work with, to get them started at all [teacher from Sweden]

Never forget how to be a child, so you can identify with children's various characters. [teacher from Germany]

At the staff-staff level, teachers highlighted the importance of having a positive collaborative relationship with the administration and other staff, particularly those teaching in the same year group and support staff (e.g. teaching assistants, in countries where they are common, such as Malta and the United Kingdom). Collaboration with the latter consisted particularly in relating the work done in class with the support given by the assistants-most preferred them to work with the child inside the classroom rather than on a withdrawal basis as has traditionally been the case with some groups of learners (e.g. those with special educational needs). As a teacher from Malta stated, 'If I talk to the complementary [support] teacher; our rapport is good enough so that if I had to ask her to do something, for instance once I sent her the copybook and I write to her, 'Can you please do these,' and she does 


\section{P. Bartolo et al.}

them'. On the other hand, they appreciated existing support or felt the need for more support from the administration in order to be able to be flexible with the curriculum or to get relevant resources. At a more general level though, there was an overwhelming emphasis on responsive teaching as a team (rather than individual) endeavour:

Don't be frightened to... don't think you're on your own and don't be frightened to ask colleagues about anything at all, no matter how big or small you think it is, ask colleagues their advice. [teacher from United Kingdom]

From my colleagues, yes, we cooperate and share our experience ... [teacher from Lithuania]

No, I have never had that. That is something we have always wished for, and we have brought it up many times... there is no chance to get something like that. [teacher from Germany]

The divergent case seen in the final excerpt above serves as a reminder of the differences evident within and across countries in terms of being able to draw upon other staff in the classroom. It provides a sharp contrast to practice in countries where additional support is commonplace (for example, in Malta and in the United Kingdom).

In terms of pupil-pupil collaborative relationships, the teachers in our sample held a fundamental belief that children can help each other, and that their diversity enriched this process (as one teacher from Czech Republic stated, 'for all of us differences are contribution'). As such they deliberately provided opportunities for them to interact together, seeing such interaction as sometimes effective in evoking a child's particular strengths. They created opportunities for children to build relationships in sometimes contrasting ways, both by asking them which child they preferred to collaborate with, but also by periodically getting them to work with unknown peers to build new friendships:

We just try and vary it as much as possible so that all the children are working with each other and relationships are going to develop outside the friendship groups really. [teacher from United Kingdom]

Or sometimes, there's the question of whom you sit them next to. If you sit them next to a friend who can help them, or who they feel confident enough to ask for help or who they can share ideas with, that helps them develop and, sometimes it brings them out of their shell, and you can find out what they're good at. [teacher from Malta]

During these lessons I try to create as much social interaction between the children as possible. For me this is just as important as the result of the actual assignment. [teacher from Netherlands]

Aside from the pure social value of facilitating positive relationships between pupils, there are of course sound pedagogical benefits to establishing such practices (Watson, 2001; Buchs and Butera, 2004). Indeed, the use of 'more knowledgeable others' (to use the Vygotskyan term) to promote cognitive growth in collaborative academic activities was something that was referred to frequently (as was the notion of working within the pupil's zone of proximal development-for instance, one 
teacher from United Kingdom stated, 'I know what each child is capable of and I'll push them as far as I think - try to get them beyond what they think are capable of').

\section{Organise responsive teaching}

Many of the teachers in our sample were striking by virtue of their willingness to experiment and innovate in their attempts to facilitate the learning and participation of all pupils. Indeed, a teacher from Czech Republic remarked, 'each child teaches me something new, teaches me to seek new ways'. As a result of this, the dataset in this analytical theme was extremely diverse in nature, and it is not possible within the space constraints of this article to provide a full exploration. Instead, we focus on two related processes through which our sample organised responsive teaching. First and foremost, they dedicated time and energy for getting to know their students' characters, interests, experience and learning styles:

I think that to meet the diversity in the classroom, you have to know your pupils very much, especially... particularly... to communicate with them, cooperate... and just to rely on them, to know them and what they need. [teacher from Lithuania]

When I took over the class [I found out about]... hobbies, likes and dislikes, favourite subjects, what they don't like about teachers and why, all that. I collected these, evaluated them, and made my own notes. That helped me a lot. [teacher from Germany]

Secondly, they adapted the curriculum, mostly in terms of using multilevel goals, using different teaching strategies, and expecting different levels of products:

In order to learn and show as if we had our parents meeting today or tomorrow and could open our notebooks to our mothers... But if we opened them perhaps five or six mothers would leave the classroom crying so we put for the show, for instance, five notebooks, five drawings, five cut patterns and present in the way to so that all the pupils looked wonderful and unique and perfect. [teacher from Lithuania]

Yes and being aware of the varied learning styles and being able to teach to those learning styles and making sure that you are not teaching to the style that suits you, that you are thinking about the children and providing throughout the day, not just throughout the week. [teacher from United Kingdom]

These first two processes are, of course, directly in line with Tomlinson's (2003) model of responsive teaching (see Figure 1).

\section{Facing challenges in responding to diversity}

The process of reaching all learners, as eloquently stated by a teacher from the Czech Republic, can be conceptualised as a 'long-distance run', with considerable barriers to overcome. Indeed, the teachers in our sample spoke as frequently of such barriers as they did of the enabling factors already discussed. The barriers and challenges faced by the participants varied greatly, and were often tied in some way to national contexts. For instance, for teachers in the countries with more diverse cultural, ethnic and religious communities (such as the UK and the Netherlands), difficulties associated with these issues were more predominant: 
It is very difficult to always consider all the different cultural and religious backgrounds. Sometimes I will say something that is apparently misunderstood because of the enormous cultural difference, I find this the most difficult. [teacher from Netherlands]

The only thing that is sometimes difficult is that the children, who have been going to the mosque since they were very young, learn there that they shouldn't listen to the blond teacher who does not wear a headscarf. [teacher from Netherlands]

So you've very much got to be aware of their [pupils whose first language is not English] background, what their level of English is on a basic level. Also the fact that their English might be holding them back, but actually they've got a lot of ability in certain subjects so you've got to sort of see through the language barrier. [teacher from United Kingdom]

However, there were also barriers and challenges that were common to teachers in most countries. Among these were implementing discipline and addressing issues relating to poor behaviour, working with children with difficulties in communication and interaction, a lack of human and physical resources, the curriculum itself (in some cases considered too restrictive and in others overloaded), and in particular, problems establishing partnerships with parents:

Sometimes I meet with parents who do not have any interest about a child... These families are often with low social background. It makes me sad. [teacher from the Czech Republic]

I can't do in the morning what the parents can't do for the other three-quarters of the day. As much as I motivate them, if there's no follow-up at home, all I do is in vain. [teacher from Germany]

It should be noted, however, that establishing partnerships with parents was not seen by all participants as being problematic - as one teacher from Sweden stated, 'Some are very involved and want to know how to support [their children's learning]'. Furthermore, a teacher from Lithuania stated, 'my contacts with the parents... and cooperation is continuous and very close and based not just on the afternoon meetings or events or class meetings but also it takes place daily, as the parents come to collect their children and if any problem emerges ... then the family helps ... I experience no difficulties in dealing with the parents'. What is perhaps more noteworthy than the barriers themselves, though, is the dogged determination of the teachers to overcome them:

And most of all, never give up. Always be optimistic. There are always throwbacks and failures, but one should not let that get one down. [teacher from Germany]

\section{Conclusion}

The aim of this qualitative study was to elicit from teachers' perceptions and descriptions of issues related to responding to the diversity of students' strengths and needs in actual classrooms. The five major themes and sub-themes raise several important issues that teachers who are interested in reaching out to all children need to address. As previously mentioned, they were not meant to give a 'generalisable' or 'representative' picture of what is actually going on in all classrooms, but rather what 
is possible to achieve in real classrooms with teachers who are faced with, as one teacher from Malta observed, 'the multiplicity of demands in actual classroom contexts'.

Much of our findings link directly with the current literature on the development of inclusive practices within schools. In a similar vein to authors such as Ainscow et al. (2004), we found that facilitating the learning and participation of all pupils is best understood as the adoption of a set of values and principles rather than a series of explicit 'tips'. Like Tomlinson (2003), we also found that teachers striving to practice inclusively need to address and explore not only the diversity inherent in their pupils, but also to ask questions about the diverse nature of what is to be taught and how it may be taught across the curriculum. The findings point to the importance of training teachers to reflect on their implicit approaches to classes and the curriculum in order to develop an appreciation of the potential enrichment of diversity. Above all, inclusion is best understood as a process; as a teacher from Germany noted, 'the way is the goal'.

\section{Notes on contributors}

Dr Neil Humphrey is a Lecturer in educational psychology at the School of Education, University of Manchester, United Kingdom.

Dr Paul Bartolo is Senior Lecturer in educational psychology at the Faculty of Education, University of Malta, and Coordinator of the Comenius 2.1 DTMp Project on 'Differentiated Teaching Module (primary)'.

Peter Ale is Head of teacher education for primary at the Educatieve Hogeschool van Amsterdam, Netherlands.

Colin Calleja is a Lecturer in differentiated teaching at the Faculty of Education, University of Malta.

Dr Thomas Hofsaess is Head of the Department of Learning Disability, University of Leipzig, Germany.

Vera Janikova is Director of the NGO organisation 'Motivace-Zivotni Styl', Czech Republic.

Annemieke Mol Lous is a Lecturer in educational psychology at the Educatieve Hogeschool van Amsterdam, Netherlands.

Vida Vilkiene is a Lecturer in Second Language Learning and International Coordinator at Marijampole College, Lithuania.

Gun-Marie Wetso is a Lecturer in teacher education for special needs, Department of Health and Social Sciences, University of Dalarna, Sweden.

\section{References}

Ainscow, M., Howes, A., Farrell, P. \& Frankham, J. (2003) Making sense of the development of inclusive practices, European fournal of Special Needs Education, 18(2), 227-242.

Ainscow, M., Booth, T. \& Dyson, A. (2004) Understanding and developing inclusive practices in schools: a collaborative action research network, International fournal of Inclusive Education, 8, 125-139. 
Benincasa, L. (2002) Teaching pre-schoolers about diversity: a view from Greece, fournal of Education for Teaching, 28(2), 103-122.

Booth, T. \& Ainscow, M. (2002) Index for inclusion (Revised Edition, Bristol, CSIE).

Buchs, C. \& Butera, F. (2004) Socio-cognitive conflict and the role of student interaction in learning, New Review of Social Psychology, 1, 80-87.

Donnelly, C. (2004) What price harmony? Teachers' methods of delivering an ethos of tolerance and respect for diversity in an integrated school in Northern Ireland, Educational Research, $46(1), 3-16$.

Eurydice (1994) Measures to combat failure at school: a challenge for the construction of Europe (Brussels, Eurydice).

Eurydice (2002) Key topics in education in Europe, Vol. 3: The teaching profession in Europe: profile, trends and concerns Report I -initial training and transition to working life (Brussels, Eurydice).

European Commission Directorate General for Education and Culture (2003) Improving education of teachers and trainers: progress report (Brussels, European Commission).

European Communities (1997) Treaty of Amsterdam Available online at: http://www.unizar.es/ euroconstitucion/Treaties/Treaty_Amst.htm (accessed 24 January 2006).

Farrell, P. \& Ainscow, M. (Eds) (2002) Making special education inclusive (London, David Fulton).

Gregory, G. H. \& Kuzmich, L. (2005) Differentiated literacy strategies for student growth and achievement in Grade K-6 (Thousand Oaks, CA, Corwin Press).

Guba, E. G. \& Lincoln, Y. S. (1989) Fourth generation evaluation (Newbury Park, CA, Sage).

Lincoln, Y. S. \& Guba, E. G. (2000) Paradigmatic controversies, contradictions, and emerging confluences, in: N. K. Denzin \& Y. S. Lincoln (Eds) Handbook of qualitative research $2^{\text {nd }}$ Edition, 163-188, Thousand Oaks, CA, Sage).

McGarvey, B., Marriott, S., Morgan, V. \& Abbott, L. (1998) Approaches to differentiation in the core subjects: the experience of Northern Ireland primary teachers, Evaluation And Research In Education, 12(3), 140-152.

Meijer, J. W. (2003) Summary report: inclusive education and classroom practice Available online at www.european-agency.org (Accessed 24 January 2006).

Smith, J. A. (Ed.) (2003) Qualitative psychology (London, Sage).

Thomas, G. \& Loxley, A. (Eds) (2001) Deconstructing special education and constructing inclusion (Buckingham, Open University Press).

Tomlinson, C. A. (1999) The differentiated classroom: responding to the needs of all learners (Alexandria, VA, ASCD).

Tomlinson, C. A. (2003) Fulfilling the promise of the differentiated classroom (Alexandria, VA, ASCD).

UNESCO (1994) The Salamanca Statement and Framework for Action on Special Needs Education (Spain, Ministry of Education and Science).

UNESCO (2004) Changing teaching practices: using curriculum differentiation to respond to students' diversity (Paris, UNESCO).

UNESCO (2005) Guidelines for inclusion: ensuring access to education for all (Paris, UNESCO).

Watson, J. (2001) Social constructivism in the classroom, Support for Learning, 16, 140-148. 